\title{
Haematological and Biochemical Indices of Growing Lambs Fed Fore-Stomach Digesta and Poultry Litter Waste
}

\author{
${ }^{* 1}$ A. Aruwayo, ${ }^{2}$ Maigandi, S.A., Malami, B.S., and Daneji, A. I. \\ 1 National Productivity Centre, P. O. Box, 4243, Sokoto \\ 2 Department of Animal Science, Faculty of Agriculture, Usmanu Danfodiyo University, Sokoto \\ 3Department of Animal Science, Faculty of Agriculture, Usmanu Danfodiyo University, Sokoto \\ 4 Department of Medicine, Faculty of Veterinary Medicine, Usmanu Danfodiyo University, Sokoto \\ [* Corresponding Author:adebayoar@yahoo.com; $\mathbf{E}+\mathbf{2 3 4}(\mathbf{0}) \mathbf{8 0 3 5 8 1 3 3 7 7 ]}$
}

\begin{abstract}
Haematological values and blood urea nitrogen levels of growing Uda lambs fed forestomach digesta (FSD) and poultry litter waste (PLW) were studied. The experimental animals were randomly allotted ( $\mathrm{n}=4 /$ treatments) to diets A (20\% FSD), B (20\% PLW), C (10\% each of FSD and PLW), D (6.67\% FSD and 13.33\% PLW) and E (13.33\% FSD and 6.67\% PLW). The experiment lasted for 84 days. Blood samples were collected prior to and after the feeding trial for haematological and blood urea nitrogen determination. Initial packed cell volume and final red blood cell counts were not significantly different between treatments $(\mathrm{P}>0.05)$. Initial haemoglobin concentration $(\mathrm{HB})$ was similar $(\mathrm{P}>0.05)$ to those on treatments $\mathrm{A}, \mathrm{C}, \mathrm{D}$, and $\mathrm{E}$ while final $\mathrm{HB}$ concentration was similar $(\mathrm{P}>0.05)$ for those on treatments $\mathrm{B}, \mathrm{C}$, and $\mathrm{E}$. Initial and final values of neutrophil and lymphocyte counts were not significantly different $(\mathrm{P}>0.05)$ for all treatments. There were no traces of eosinophils at the end of the feeding trial while monocyte counts were not significantly different $(\mathrm{P}>0.05)$ at the beginning and end of the feeding trial. Total protein showed no significant difference in all the treatments at initial and final collections of blood. Similar results were observed for albumin and globulin concentrations. Haematological values and blood urea nitrogen were within normal values; indicating that there was no toxicity associated with the feeding of FSD and PLW alone or in mixtures to growing lambs. It was concluded that the test diets were not toxic to animals based on the haematological indices and blood biochemical parameters which were within recommended values.
\end{abstract}

Key Words: Lambs, Fore-Stomach Digesta, Poultry Litter Waste

\section{INTRODUCTION}

The cost of feed ingredients has increased tremendously over the years and this has been a source of worry for livestock producers. The contemporary issue in livestock management is the exorbitant cost of feeding stuffs. This is obviously a matter of concern because of the fact that feeds account for about $60-80 \%$ of the recurrent expenditure of intensive animal production system (Onifade, 1993).

Astronomical increase in population of Nigeria $(140,431,790$ million) (NPC, 2006) is not backed by a commensurate increase in the production of grains and other crops that are also consumed by man.

In view of the fact that feeding problems constitute the single largest problem of ruminant production in Nigeria, it is important to consider the use of alternative feed ingredients in order to reduce cost of production and optimize profit for improved livestock performance enterprise. These alternative feed ingredients which can be sourced from our environment referred to as non conventional feedstuffs. Commonly used non-conventional feed stuffs include municipal waste, domestic refuse, animal excreta, rumen content, tannery wastes and other products (Boda, 1990). Reddy and Reddy (1980) reported that the dry matter of rumen digesta from ovine species ranged from 12 to $20 \%$ and crude protein 7.9 to $19.3 \%$. According to Kamphues (1980), stomach content from cattle had an average weight of 42 to $45 \mathrm{~kg}$ with the following composition: $12.9 \%$ ash, $16.1 \%$ crude protein, $2.7 \%$ fat, $30.0 \%$ crude fibre, $14.9 \%$ lignin and $38.3 \%$ NFE. Maigandi (2001) reported that the chemical composition of animals slaughtered at Sokoto abattoir had an average of $15.79 \%$ $\mathrm{DM}, \quad 8.56 \% \mathrm{CP}, 6.35 \% \mathrm{EE}, 33.07 \% \mathrm{CF}$, 41.29\% NFE and $10.84 \%$ Ash.

Fore-stomach digesta (FSD) is one of the waste products that can be used as alternative 
feed ingredient. It is an abattoir bye-product obtained from the fore-stomach of camels, cattle, sheep and goats. The rumen contains appreciable amount of nutrients that support animal performance (Boda, 1990).

Another waste product of importance for livestock feeding consideration is poultry litter waste. The chemical composition of poultry excreta, especially the high nitrogen content, suggests that feeding it to ruminants would be an excellent way of converting nutrients in the waste into proteins for human consumption.

Feeding unconventional feeds such as animal waste may cause metabolic disturbance (FAO, 1980). However, despite the assumed potential risks of feeding animal waste to livestock, no scientific evidence shows that animal waste recycling poses any heath risk, provided the waste is properly processed and the ratio in diets carefully balanced (FAO, 1980). This study was designed to evaluate the haematological indices and biochemical parameters of lambs fed fore-stomach digesta and poultry waste, fed as a mixture or alone.

\section{MATERIALS AND METHODS}

This study was conducted at the Livestock Teaching and Research Farm of Usmanu Danfodiyo University, Sokoto, between
September and October, 2005. Twenty growing male Uda lambs with average body live weight of $19.80 \mathrm{~kg}$ were used. The experimental lambs were quarantined for two weeks, dewormed with Bannath 11R dewormer at the rate of $12.5 \mathrm{~kg} / \mathrm{kg}$ body weight, sprayed against ectoparasite with triatic and treated with oxytetracycline (a broad spectrum antibiotic) through intramuscular injection.

\section{Experimental Procedure}

Five experimental diets were formulated and tested with four animals per treatment in a completely randomized design. The experimental diets contained FSD and PLW incorporated into other ingredients at various levels. Treatment A contained 20\% FSD, B 20\% PLW, C 10\% each of FSD and PLW, D 6.67\% FSD and $13.33 \%$ PLW and E $13.33 \%$ FSD and $6.67 \%$ PLW. The forestomach digesta (FSD) were sourced from camel, cattle, sheep and goats. The mixture was sun-dried for a period of 15 days. The poultry litter waste (PLW) obtained from layers from a farm in Sokoto was also sundried for 15 days before use. The gross compositions of the experimental diets are shown in Table 1.

Table 1: $\quad$ Gross Composition of the Experimental Diets

\begin{tabular}{llllll}
\hline Ingredients (\%) & \multicolumn{5}{c}{ Diets } \\
\cline { 2 - 6 } & $\mathrm{A}$ & $\mathrm{B}$ & $\mathrm{C}$ & $\mathrm{D}$ & $\mathrm{E}$ \\
\hline FSD & 20 & - & 10 & 6.67 & 13.33 \\
PLW & - & 20 & 10 & 13.33 & 6.67 \\
Maize & 2 & 2 & 5 & 4 & 2 \\
Groundnut hay & 15 & 7 & 7 & 3 & 15 \\
CSC & 32 & 22 & 29 & 26 & 29 \\
Wheat offal & 20 & 13 & 14 & 16 & 13 \\
Cowpea Husk & 4 & 3 & 3 & 4 & 9 \\
Rice milling waste & 5 & 31 & 20 & 25 & 10 \\
Bone meal & 1 & 1 & 1 & 1 & 1 \\
Salt & 1 & 1 & 1 & 1 & 1 \\
Total & 100 & 100 & 100 & 100 & 100 \\
\hline
\end{tabular}

Each group of the experimental animals was assigned to one of the experimental diets and was fed ad-libitum in the morning and evening for 84 days. Thoroughly mixed representative samples of the five experimental feeds, FSD, and PLW were analyzed for proximate composition as outlined by AOAC (2000). The proximate composition of experimental diets is shown in table 2. Water was also offered $a d$ libitum.

\section{Blood Samples Collection and Analysis}

Blood samples were collected from each animal before commencement of the feeding trial and at the last week of the experiment. The samples were collected from the jugular vein (Coles, 1986). Bleeding was done early in the morning before feeding. An average of $10 \mathrm{ml}$ of blood was collected from each animal. About $3 \mathrm{ml}$ of each was placed in an EDTA (anti-coagulant) bottle for haematological 
studies. The remaining $7 \mathrm{mls}$ were placed in universal bottle and allowed to stand for about 2 hours at room temperature. The universal bottles were thereafter centrifuged at $700 \times \mathrm{g}$ for 15 minutes, the serum separated, decanted and stored in a freezer at $-10^{\circ} \mathrm{C}$ for blood biochemical parameters tests. According to Cyanomethemoglobin method (Coles, 1986), Whole blood samples were analyzed for haemoglobin content.

\section{Data Analysis}

Data generated from the experiment was subjected to analysis of variance (ANOVA) using completely randomized design (CRD) according to the methods of Steel and Torrie (1980). Mean separation were done according to Multiple Range Test (DMRT) for mean separation (Duncan, 1955).

\section{RESULTS}

Proximate composition of the experimental diets and test ingredients is presented in Table 2. Dry matter of the experimental diets varied from $94.0 \%$ for treatment $\mathrm{E}$ to $95.0 \%$ for treatment B. Crude protein $(\mathrm{CP})$ content ranged from $16.02 \%$ for treatment $\mathrm{D}$ to $16.07 \%$ for treatment E. Ether extract value ranged from $8.20 \%$ for treatment A to $9.30 \%$ for treatment $\mathrm{D}$ while crude fibre varied between $23.18 \%$ for treatment $\mathrm{E}$ to $24.06 \%$ for treatments $\mathrm{C}$ and $\mathrm{D}$. The ash content varied from $10.90 \%$ for treatment B to $11.60 \%$ for treatment D. Treatment D contained the lowest nitrogen free extract (NFE) with $39.02 \%$ while the highest $(41.15 \%)$ was for treatment $\mathrm{E}$

Table 2: Proximate Composition of Experimental Diets.

\begin{tabular}{llllllll}
\hline \multicolumn{1}{c}{ Parameters (\%) } & \multicolumn{7}{c}{ Treatments } \\
\cline { 2 - 8 } & \multicolumn{1}{c}{$\mathbf{A}$} & \multicolumn{1}{c}{ B } & \multicolumn{1}{c}{ C } & D & E & FSD & PLW \\
\hline Dry matter & 94.5 & 95.0 & 94.50 & 94.50 & 94.00 & 95.60 & 94.0 \\
Crude protein & 16.05 & 16.06 & 16.06 & 16.02 & 16.07 & 9.00 & 25.0 \\
Ether extract & 8.20 & 8.60 & 7.90 & 9.30 & 8.40 & 5.50 & 6.7 \\
Crude fibre & 24.03 & 23.93 & 24.06 & 24.06 & 23.18 & 35.0 & 12.0 \\
Ash & 11.50 & 10.90 & 11.0 & 11.60 & 11.20 & 40.50 & 49.47 \\
NFE & 40.25 & 40.51 & 40.98 & 39.02 & 41.15 & 10.00 & 6.8 \\
Energy $(\mathrm{kca} / \mathrm{kg})$ & 4201.68 & 3372.88 & 3771.90 & 3564.53 & 4000.31 & 123 & 185 \\
\hline
\end{tabular}

Note: the energy quoted in this table is calculated.

Table 3 shows the haematological parameters of experimental animals. Initial packed cell volume (PCV) was not significantly different between treatments $(\mathrm{P}>0.05)$. Also, the values of PCV at the end of the experiment were not significantly different $(\mathrm{P}>0.5)$ for animals on treatments $\mathrm{A}, \mathrm{C}, \mathrm{D}$ and $\mathrm{E}$ with the exception those on treatment B (33.50\%). Similarly, final $\mathrm{Hb}$ concentration of blood was similar ( $\mathrm{P}>0.05)$ for animals on treatments B, C and E. However, those for treatments $\mathrm{C}(10.33 \mathrm{~g} / \mathrm{dl})$ and E $(9.55 \mathrm{~g} / \mathrm{dl})$ were not significantly different from that of A $(8,25 \mathrm{~g} / \mathrm{dl})$. Animals for treatment $\mathrm{A}$ were similar to those for treatments E $(9.55 \mathrm{~g} / \mathrm{dl})$ and $\mathrm{D}(7.60 \mathrm{~g} / \mathrm{dl})$ $(\mathrm{P}>0.05)$. Red blood cells (RBC) concentration was not significantly different $(\mathrm{P}>0.05)$ among the treatments for both initial and final blood samples. Initial white blood cell concentration were not significantly different for treatments C. D, and E but significantly different
$(\mathrm{P}<0.05)$ for treatments $\mathrm{B}$ and $\mathrm{A}$. Final white blood cell concentration were similar for animals on treatments $\mathrm{E}, \mathrm{D}, \mathrm{C}$ and $\mathrm{B}$ which were significantly different from that of treatment A.

From the results in Table 4, it can be seen that initial and final values of neutrophils were not significantly different $(\mathrm{P}>0.05)$ among treatments. The same trend was observed for lymphocyte count. The monocyte count for animals at both the beginning and end of the feeding trial was not significantly different $(\mathrm{P}>0.5)$. Some traces of eosinophils were observed at the initial stage of the experiment for animals on treatments E $1.50 \%, \mathrm{C} 1.0 \%$, B $0.5 \%$ and $\mathrm{D} 0.5 \%$. There were no traces of basophil in all the treatments at the beginning and end of the feeding trial. 
Table 3: Haematological Characteristics of the Growing Lamb Fed FSD and PLW Alone or in Mixtures.

\begin{tabular}{lllllll}
\hline \multicolumn{1}{c}{ Parameters } & \multicolumn{7}{c}{ Treatments } \\
\cline { 2 - 7 } & \multicolumn{1}{c}{$\mathbf{A}$} & \multicolumn{1}{c}{ B } & \multicolumn{1}{c}{ C } & \multicolumn{1}{c}{ D } & E & SE \\
\hline Packed cell vol (\%) & & & & & & \\
Initial & 32.25 & 30.50 & 32.0 & 33.50 & 32.50 & 3.125 \\
Final & 31.25 & 33.50 & 33.25 & 32.0 & 30.00 & 2.253 \\
$\begin{array}{l}\text { \% Difference } \\
\text { Hemoglobin Concentration }\end{array}$ & -3.10 & 9.8 & 3.91 & -4.48 & -7.69 & \\
$\quad$ Initial (g/dl) & $10.20^{\mathrm{a}}$ & $6.53^{\mathrm{b}}$ & $7.35^{\mathrm{ab}}$ & $9.48^{\mathrm{ab}}$ & $8.85^{\mathrm{ab}}$ & 1.049 \\
$\quad$ Final (g/dl) & $8.25^{\mathrm{bc}}$ & $11.08^{\mathrm{a}}$ & $10.33^{\mathrm{ab}}$ & $7.60^{\mathrm{c}}$ & $9.55^{\mathrm{abc}}$ & 0.796 \\
\% Difference & -19.12 & 69.68 & 40.54 & -19.83 & -7.9 & \\
Red Blood cell Count & & & & & & \\
$\quad$ Initial(X1012/1) & 6.20 & 4.85 & 5.45 & 5.88 & 5.80 & 0.490 \\
$\quad$ Final(X1012/1) & 7.18 & 5.08 & 5.30 & 6.25 & 6.45 & 1.008 \\
\% Difference & 15.81 & 4.74 & -2.75 & 6.29 & 11.21 & \\
White Blood cell Count & & & & & & \\
$\quad$ Initial(X10 $/ 1)$ & $5.45^{\mathrm{b}}$ & $5.95^{\mathrm{b}}$ & $6.85^{\mathrm{a}}$ & $6.73^{\mathrm{a}}$ & $6.28^{\mathrm{a}}$ & 0.933 \\
$\quad$ Final(X10\%/1) & $4.60^{\mathrm{b}}$ & $5.70^{\mathrm{a}}$ & $5.85^{\mathrm{a}}$ & $5.88^{\mathrm{a}}$ & $6.15^{\mathrm{a}}$ & 1.176 \\
\% Difference & -16.0 & -4.20 & -14.60 & 12.63 & -2.08 & \\
\hline
\end{tabular}

Means not followed by same letters are significantly different $(\mathrm{p}<0.05)$ along the same row.

Table 4: Blood components of the growing lambs fed FSD and PLW alone or in mixtures.

\begin{tabular}{lllllll}
\hline \multirow{2}{*}{ Parameters } & \multicolumn{7}{c}{ Treatments } \\
\cline { 2 - 7 } & \multicolumn{1}{c}{$\mathbf{A}$} & \multicolumn{1}{c}{$\mathbf{B}$} & $\mathbf{C}$ & $\mathbf{D}$ & \multicolumn{1}{c}{$\mathbf{E}$} & \multicolumn{1}{c}{ SE \pm} \\
\hline Neutrophils & & & & & & \\
$\quad$ Initial (\%) & 48.50 & 56.00 & 52.25 & 48.50 & 52.25 & 4.59 \\
$\quad$ Final (\%) & 32.25 & 26.50 & 33.00 & 27.25 & 19.25 & 6.595 \\
\% Difference & -33.51 & -52.68 & -36.84 & -43.81 & -63.16 & \\
Lymphocytes & & & & & & \\
$\quad$ Initial (\%) & 51.00 & 63.25 & 39.75 & 46.25 & 41.00 & 4.811 \\
$\quad$ Final (\%) & 52.00 & 63.25 & 66.25 & 63.00 & 71.00 & 5.963 \\
\% Difference & 1.46 & 65.36 & 66.67 & 36.22 & 73.18 & \\
Monocytes & & & & & & \\
$\quad$ Initial (\%) & 7.25 & 5.50 & 7.00 & 4.75 & 5.25 & 1.349 \\
$\quad$ Final (\%) & 5.00 & 10.25 & 10.75 & 9.75 & 9.75 & 2.117 \\
\% Difference & -31.03 & 46.34 & 53.57 & 105.26 & 85.71 & \\
Eosinophils & & & & & & \\
$\quad$ Initial & 0 & 0.50 & 1.0 & 0.50 & 1.50 & \\
$\quad$ Final & 0 & 0 & 0 & 0 & 0 & \\
\% Difference & 0 & -100 & -100 & -100 & -100 & \\
\hline
\end{tabular}

Urea concentration of experimental animals for all treatments were similar $(\mathrm{P}>0.05)$ except for animals on treatment $\mathrm{D}$ and $\mathrm{E}$ which were significantly different $(\mathrm{P}<0.05)$. Total protein for all animals on treatments showed no significant difference across the treatments at both initial and final blood samples collected. The same trend was also observed for albumin and globulin concentrations for all the treatments. 
Table 5: Blood Urea Nitrogen (BUN) and Total protein in serum of the growing lambs fed FSD and PLW alone or in mixtures.

\begin{tabular}{lllllll}
\hline \multicolumn{1}{c}{ Parameters } & \multicolumn{9}{c}{ Treatments } \\
\cline { 2 - 7 } & \multicolumn{1}{c}{$\mathbf{A}$} & \multicolumn{1}{c}{$\mathbf{B}$} & \multicolumn{1}{c}{$\mathbf{C}$} & \multicolumn{1}{c}{$\mathbf{D}$} & \multicolumn{1}{c}{$\mathbf{E}$} & SE \pm \\
\hline Urea Conc (mmol/l) & & & & & & \\
$\quad$ Initial & $5.30^{\mathrm{ab}}$ & $5.59^{\mathrm{ab}}$ & $5.71^{\mathrm{ab}}$ & $6.34^{\mathrm{a}}$ & $4.67^{\mathrm{b}}$ & 0.395 \\
$\quad$ Final & 5.23 & 5.29 & 5.55 & 5.20 & 5.18 & 0.387 \\
\% Difference & -1.32 & -5.37 & -2.80 & -17.98 & -10.92 & \\
Total protein g/dl & & & & & & \\
$\quad$ Initial & 4.74 & 5.27 & 5.23 & 5.03 & 5.19 & 0.483 \\
$\quad$ Final & 5.00 & 6.09 & 5.78 & 4.99 & 5.54 & 0.353 \\
\% Difference & 5.49 & 15.56 & 10.52 & -0.80 & 6.74 & \\
Albumin (g/dl) & & & & & & \\
$\quad$ Initial & 3.69 & 3.44 & 3.50 & 3.75 & 3.82 & 0.236 \\
$\quad$ Final & 3.42 & 3.31 & 3.92 & 3.50 & 3.82 & 0.201 \\
\% Difference & -7.31 & -3.78 & 12.00 & -6.67 & 0.0 & \\
Globulin (g/dl) & & & & & & \\
$\quad$ Initial & 1.05 & 1.82 & 1.73 & 1.43 & 1.37 & 0.451 \\
$\quad$ Final & 2.18 & 2.78 & 1.87 & 1.49 & 1.71 & 0.312 \\
\% Difference & 107.62 & 52.75 & 9.25 & 4.20 & 24.82 & \\
\hline
\end{tabular}

Means not followed by same letters are significantly different $(\mathrm{p}<0.05)$ along the same row.

\section{DISCUSSION}

Crude protein content of the experimental diets fell within the crude protein requirement of $15-18 \%$ for growing lambs as reported by Church (1978) and ARC (1990). The ether extract, crude fibre and nitrogen free extract values of the diets fed to growing lambs for this study were comparable to those reported by Adebowale and Taiwo (1996) when crop residues and agro-industrial by-products to West Africa Dwarf sheep were in a feeding trial.

The low PCV and haemoglobin values observed for animals on treatments A, D and $\mathrm{E}$, in treatment $\mathrm{C}$ for red blood cells and in all the treatments for white blood cells did not portend any danger to the health of the animals since the values fell within the normal ranges of PCV (24-25\%) and $\mathrm{Hb}(8-16 \mathrm{~g} / \mathrm{dl})$ for growing sheep (Coles, 1986). The increase in their values after the feeding trial may be due to improved nutrition.

Initial and final RBC was slightly lower than the values of $8-15 \times 10^{12} / \mathrm{L}$ reported for sheep by Coles (1986). However, final RBC increased slightly compared with initial RBC. This could have been due to inadequate nutrition of the lambs before the experiment which was improved with experimental diet. Swenson (1990) reported that nutritional status of animals can affect the RBC count. WBC counts were within the normal values of 4-
$12 \times 10^{9} / \mathrm{L}$ for sheep (Jain, 1993). This shows that animals were healthy (Frandson and Spurgeon, 1992). This result of RBC and WBC counts showed that feeding animal waste like FSD and PLW to growing lambs did not cause heath hazard to the animals since the average daily gain of the experimental animals with values of $80.35 \mathrm{~g} / \mathrm{d}, 73.50 \mathrm{~g} / \mathrm{d}, 71.94 \mathrm{~g} / \mathrm{d}$ and $62.22 \mathrm{~g} /$ day for treatments C, B, D and E were comparable to the value of $61.05 \mathrm{~g} / \mathrm{d}$ for animals on treatment $\mathrm{A}$.

This could be confirmed from the values of differential counts, which are possible indicators of health problems in animals (Frandson, 1981) as reported by Maigandi (2001). Lack of basophil at the initial and final stages of the study was in agreement with Coles (1986), Swenson (1990), Frandson and Spurgeon (1992) who reported that lack of basophil in blood is an indication of disease free condition. Traces of eosinophil were found at the beginning of the study but not at the end of the study. Lack of eosinophil signifies absence of parasitic infection (Frandson and Spurgeon, 1992). This could be due to the spraying of the animals against ecto-parasite using triatic at beginning of the experiment thereby eliminating the parasites that could have infested them and the animals were subsequently kept safe from parasitic infestation. 
Values of urea, total protein, albumin and globulin obtained at the beginning and end of the study fell within normal ranges for small ruminants generally as reported by Coles (1986) and specifically for West African Dwarf Goat (Aina and Akinsoyinu, 1996).

\section{CONCLUSION}

Values obtained in this study for haematological indices and blood biochemical parameters at the end of the experiment were within the recommended levels, therefore, the test diets were not toxic to the animals and as such fit for growing lambs consumption.

\section{REFERENCES}

A.O.A.C. (2000). Association of Official Analytical Chemistry. Official methods of Analysis ,15 ${ }^{\text {th }}$ ed. . Vol 1, Arlington, Virginia.

Adebowale, E. A. and Taiwo, A. A. (1996). Utilization of crop residues and agro industrial by-products as complete diets for West African Dwarf sheep and goats. Nig. J. Animal Prod., 23(1):153160

Aina, A. B. J. and Akinsoyinu, A. O. (1996). Effect of dietary copper supplementation on serum copper level and performance of female West African dwarf goats. Nig. J. Animal Prod., 23 (1): 61-65.

ARC. (1990). The Nutrient Requirement of Ruminant Livestock. Technical Review by an Agricultural Research Council working party. C.A.B. International, Wallingford, Oxon.

Boda, K. (1990). Non-conventional feedstuffs in the nutrition of farm animals. Elsievier Science Publishing Company Inc., New York United States of America.

Church, D. (1978). Livestock feeds and feeding. Oxford Press, Portland, Oregon, United States of America.

Coles, E. H. (1986). Veterinary Clinical Pathology ( $4^{\text {th }}$ edition). W.B. Sanders Company, Harcourt Brace Jovanovich, Inc., United States of America.

Duncan, D. B. (1955). Multiple Ranges and Multiple F-Test. Biometrics, 11:1-42.

FAO (1980). Food and Agriculture Organisation of United Nations. Feed from Animal wastes: Stages of knowledge. Vol. 18, FAO, Rome, Italy.
Frandson, R. D. (1981). Anatomy and Physiology of Farm animals. ( ${ }^{\text {rd }}$ ed). Lea and Febiger, Bailliere Tindal, London.

Frandson, R. D. and Spurgeon, T.L. (1992). Anatomy and Physiology (4 ${ }^{\text {th }}$ ed.) Lea and Febiger, London.

Grant, G. H. (1987). Amino Acids and Protein. In: Fundamentals of Chemical Chemistry. Third Edition; Tietz, N.W. (Ed), WB Sannders Company Philadelphia USA, p328-329, 1987.

Henry, R. J. and Stobel, C. (1957). Determination of serum proteins by the burette reaction. Analytical Chemistry; 92:1491.

Jain, N. C. (1993). Physiology of blood with some comments on response to disease. Int. J.Anim. Sci. 8: 195-231.

Maigandi, S. A. (2001). Quantification and utilization of fore-stomach digesta in the diets of growing and fattening sheep. Ph.D Thesis. Department of Animal science, Faculty of Agriculture, Usmanu Danfodiyo University, Sokoto, Nigeria. $129 \mathrm{pp}$.

NPC (2006). Nigeria-Lagos City Local Government Areas: Federal, State and Local Government. htt: //www.citypopulation.de/NigriaLagos.html

Onifade, A. A. (1993). Comparative utilization of three dietary fibre sources by Broiler chickens. Ph.D Thesis. Dept of Animal Science, University of Ibadan, Nigeria.

Steel, R. G. D. and Torrie, J. H (1980). Principles and Procedures of Statistics. McGraw Hill Book Co. Inc. N.Y., USA.

Swenson, M. J. (1990). Physiological Properties, Cellular and Chemical Constituents of Blood: Duke's Physiology of Domestic Animals. $10^{\text {th }}$ ed., Cornell University Press, London, U.K.

Tannis, R. J. and Maylor, A. W. (1968). Physical and Chemical studies of low molecular weight form of cheese. Biochemical. J. 108:771. 